TEME, г. XLII, бр. 3, јул - септембар 2018, стр. 779-797

Прегледни рад

DOI: $10.22190 /$ TEME1803779S

Примљено: 21. 4. 2017.

UDK 355.351316 (Берк. E)

Ревидирана верзија: 25. 10. 2017.

Одобрено за штампу: 12. 6. 2018.

\title{
БЕРКОВ ДОПРИНОС ПРОУЧАВАҢУ ВОЈСКЕ КАО ДРУШТВЕНЕ ИНСТИТУЦИЈЕ
}

\author{
Срђан Старчевић ${ }^{1 *}$, Илија Кајтез ${ }^{2}$ \\ ${ }^{1}$ Универзитет одбране Војна академија, Београд, Србија \\ ${ }^{2}$ Универзитет „Унион - Никола Тесла”, \\ Факултет за међународну политику и безбедност, Београд, Србија \\ srdjan.starcevic@vs.rs
}

\begin{abstract}
Апстракт
Критикујући друштвене догађаје у Француској у току Француске буржоаске револуције, Едмунд Берк се, између осталог, бавио и војним питањима настојећи да критиком промена које је револуција унела у војну организацију и њену употребу покаже узалудност и штетност револуције. У овом раду се анализирају три врсте његових аргумената против реформе војске у Француској с циљем да се провери актуелност Беркових ставова о војној организацији. То су аргументи против избора војних старешина на официрске дужности, аргументи против слабог врховног команданта, аргументи против деловања политичких странака у војсци и политичког ангажовања војника. Као кључне друштвене односе који морају да владају у војсци Берк је истицао дисциплину (унутрашњи функционални однос) и потчињавање (спољни функционални однос, према цивилној власти). Потцртао је монистичност и политичку неутралност војске као њене битне особине и први је аутор који је на недвосмислен начин указао на однос официра и војника као на средишњу тачку структуре једне војске. Доказао је да војна реформа у Француској за време револуције води у војну диктатуру, али није уочио да ова реформа означава и напуштање феудалне најамничке армије као облика организовања војске и стварање услова за увођење масовне армије засноване на општој војној обавези. Његова схватања односа војне и цивилне сфере сврставају га међу претече савремених теорија цивилно-војних односа.
\end{abstract}

Кључне речи: Едмунд Берк, револуција, војска, цивилно-војни односи. 


\title{
BURKE'S CONTRIBUTION TO THE STUDY OF THE MILITARY AS THE SOCIAL INSTITUTION
}

\begin{abstract}
Criticizing the social events in France during the French Revolution, Edmund Burke also dealt with military issues. He criticized the changes that the Revolution brought in the military organization in order to demonstrate the futility and harmfulness of the revolution. In this paper we have analyzed three types of his arguments against the reform of the army in France in order to check if those aspects of Burke's views on military are still valid. These are arguments against electing military officers for officers' duties, the arguments against a weak supreme commander and the arguments against interfering of political parties in the military and against political engagement of the soldiers. As a key social relationship that must prevail in the military, Berk emphasized discipline (as an internal functional relationship) and subordination (an external functional relationship, which refers to subordination to civil authorities). He underlined singularity and political neutrality of the military as its essential characteristics. He was the first to unequivocally point to the connection between officers and soldiers as the central point of the structure of a military. He proved that the military reform in France during the revolution would lead to a military dictatorship, but he failed to note that the reform also meant the abandonment of feudal mercenary military as a form of organization, as well as creating conditions for the introduction of a mass military based on general conscription. His understanding of the relations between military and civilian spheres, makes him one of the forerunners of the modern theories of civil-military relations.
\end{abstract}

Key words: $\quad$ Edmund Burke, revolution, military, civil-military relations.

\section{УВОД}

Француска буржоаска револуција задала је снажан ударац феудализму и отворила врата за ново друштвено уређење, засновано на разуму и вери у могућност непрекидног развоја човекових хуманих и рационалних могућности, које је сањао просветитељски 18. век. У току ове револуције одиграла се и једна од највећих трансформација рата и војске: започето је кретање од ограниченог европског рата ка тоталном рату (Клаузевиц, 1951, стр. 499; Kreveld, 2010, str. 49) и створена прва масовна војска пред којом су се до тада преовлађујуће феудалне стајаће најамничке војске показале немоћнима (Павловић, 1909, стр. 32; Esdaile, 2007, p. 9-14). Реформа војске није протекла без озбиљних неслагања међу самим револуционарима нити без еволуције почетних идеја приликом њиховог судара са стварношћу ратних пораза. Посебно се међу јакобинцима развила одбојност према најамничкој војсци као опасности за револуцију и републику. Мара je (Jean-Paul Marat, 1743-1793) предлагао наоружавање народа ради победе револуције у унутрашњој борби и формирање „париске армиje" састављене од наоружаних грађана који сами бирају своје официpe, с тим да ови могу бити бирани само на три месеца и могу да буду смењени у сваком тренутку. Опасност од злоупотребе војске Мара је 
желео да реши њеним омасовљењем - она треба да буде организациjа револуционарног народа (Vjatr, 1987, str. 82-87). Сен-Жист (Louis Antoine Léon de Saint-Just, 1767-1794), који је био принуђен да своје теорије о војсци опроба и у пракси, одступио је од доктрине коју је заступао Мара. Схвативши да конципирање војних операција засновано на старим правилима још из Седмогодишњег рата прописаним у документу познатом као 1791 Reglement није могуће с малобројним каријерним официрима (jep је велики број емигрирао) нити с новим, недовољно увежбаним трупама (Kajtez, 2017, p. 110), он се заложио за пројекат амалгама, тј. повезивања регуларних и добровољачких јединица - једни у нову армију уносе солидну војну спрему, други републикански дух. Сен-Жист је доследно бранио потребу за високом политичком свешћу војске и донекле изборе за официрске положаје, али с јасном границом: ови избори не обухватају генерале. Војску ће контролисати народ одоздо путем војничких избора, а влада одозго путем постављења команданата. Контрола одозго постала је неопходна и због корупције која је захватила војну управу (SenŽist, 1987, str. 284-288). Карно (Lazare Nicolas Carnot, 1753-1823) и Барер (Bertrand Barere de Vieuzac, 1755-1841), који су припремили августовски декрет из 1793. и организовали војску која је победила војске европских монарха, сматрали су да је неопходно да сваки грађанин буде војник, јер ако је само део грађана стално наоружан, он неизбежно потчињава своје ненаоружане суграђане. Они су излаз из опасности који је претио Француској видели у повећању броја војника, капацитета логистике, компетенција официра, дисциплине трупа и владине контроле над војском, па су увели општу војну и радну обавезу, интензивирали школовање официра, позвали под заставу официре старог режима и увели политичке комесаре који су обесмислили праксу војничких избора и ставили команданте под непосредни надзор револуционарне владе. Од 1794. године практиковале су се строге казне за дисциплинске прекршаје, што је повратило стари ауторитет официрима. Једна од далекосежних последица војних реформи започетих у Француској и усвојених од других земаља Европе јесте развој официрског професионализма који ће потпуно потиснути аристократски принцип кооптације племића у официрски кор и то тако да „никада више рођење није било формални предуслов за војни чин" (Hantington, 2004a, p. 46).

Француска револуција је од самог избијања имала своје критичаре и противнике, међу којима истакнуто место заузима Едмунд Берк (Edmund Burke, 1727-1797), британски политичар, виговац кон- 
зервативног светоназора ${ }^{1}$ и један од оних мислећих људи који су и пре конституисања социологије као науке препознавали значај друштва, друштвених снага и облика, те на специфичан начин стајали на једном социолошком становишту који њихово дело чини вредним и данас (Hart, 1997, p. 19-20; Јовановић 1990, стр. 193).

Беркова конзервативна мисао кристализовала се у периоду од избијања Француске револуције до његове смрти, а свом творцу донела је славу родоначелника конзервативизма као политичке идеологије (Stanovčić, 2008, str. 19). Његов конзервативизам почивао је на органском схватању државе, антииндивидуализму и високом вредновању традиције, континуитета и равнотеже политичких снага као нечега што ствара услове за очување поретка. Држава је по његовом мишљењу живи организам у коме су друштвеним уговором повезане и удружене прошле, садашње и будуће генерације. Она се постепено развија, а сваки радикални политички рез омета њен развој ка најбољим решењима. Легитимност политичког поретка почива на његовој прескрипцији, чињеници да дуго постоји. Друштвени живот и развој државе не могу се заснивати на идејама појединаца јер је нагомилано искуство векова, које се понавља и прераста у предрасуде (у значењу навике), то које спаја различите генерације у мишљењу и понашању. Он је сматрао да битну улогу у држави немају појединци, него елементи цивилног друштва, што је значајно за разумевање енглеске политичке мисли (Wood, 2000, p. 238-241), или, Берковим речима, ,мали одреди”, тј. породице, братства, општине, цркве, сталежи, клубови, цехови, гилде и корпорације, које стварају људи да би задовољили своје приватне интересе. Народна заједница настаје усклађивањем ових група и институција, а као што целина претходи деловима, тако и интереси народа претходе индивидуалним интересима (Hejvud, 2004, str. 20; Mićunović, 2010, str. 113-123). Тврдио је да је одређена промена неопходна за опстанак поретка (Hejvud, 2004, str. 93), али промена која је добродошла увек израста из традиције. Мада је његова одбојност према Француској револуцији изненадила многе виговце, Беркова склоност ка глаткоћи и трајању, сентименту и

\footnotetext{
${ }^{1}$ Мада постоји дилема да ли Берка треба разумети као либерала или конзервативца (Janković, 2004), већина аутора сагласна је да је он уздигао конзервативизам на ниво идеологије и сматрају га првим конзервативцем (Robin, 2011; Norman, 2013; Дјурант, 2004; Stanovčić, 2001; Кајтез, 2009, Armitage, 2000). Такође, аутори који су проучавали Берков наизглед контрадикторан став према револуцијама (подржавао је Америчку револуцију, а критиковао Француску револуцију) углавном су сагласни да је Берк био противник само радикалних или модерних револуција (Freeman, 2010: 174-175; Welsh, 1995: 94-95; Arendt, 1990: 117). Постоје и они аутори који сматрају да дилема у вези са Берковим убрајањем у конзервативце зависи од тога шта подразумевамо под конзервативизмом (Callawey, 2016: XIII-XIV).
} 
инстинкту (а не разуму и разумевању) може се уочити већ у његовој естетици (Burke, 1767, p. 129-131, 213-214, 290-291; Byrne, 2006, p. 20-21), а он је са̂м оправдава као личну потребу да допринесе оним снагама које су у стању да поврате равнотежу лађи која се љуља и која је стога у опасности. За Беркову мисао је карактеристичан и специфични елитизам, у чијој је позадини одбрана енглеског концепта представничке демократије насталог после 1688. године који подразумева примесе олигархије (Wood, 2000, p. 217). Наиме, Берк је сматрао да је аристократија та која чува поредак од монарха, с једне стране, и светине с друге стране, док народни посланик није пуки делегат својих гласача, него део парламента чији је први циљ да дела као целина и као такав мора бити независан од својих бирача како би могао да доноси зреле одлуке и служи бирачима властитим просуђивањем (Burke, 1975, p. 157).

Мада је био противник честог посезања за ратом, који мора бити само крајње средство, и речити заговорник избегавања коришћења војне силе јер она пружа само несигурна и привремена решења (Burke, 1999, p. 236; Mićunović, 1997, str. 131), Берк се није либио да подржи, чак и да захтева да се неки рат покрене, када је сматрао да је то од суштинске важности за очување унутрашњег мира и поретка у његовој отаџбини, а можда и читавој Европи (Burke, 2010, p. 205), дакле, када је то по његовом мишљењу нужно, корисно и морално (Armitage, 2000, p. 627). Био је заговорник ратног савеза легитимних европских владара против Француске Републике, коју назива Републиком краљеубиства и Републиком убица (Burke, 2010, p. 43, 46). Овај рат је, по његовом мишљењу, нужан не само зато што је револуција претила „да промени саму природу европске политике” (Daniel \& Smith, 2015, p. 316) него и зато што је Француска револуција претворила рат у неку врсту војне егзекуције која не познаје милост и не поставља границе својим захтевима (Daniel \& Smith, 2015, p. 318). Берк се у парламенту упорно залагао за „свети рат” против младе Француске Репубике и с одушевљењем је дочекао вест да је Француска објавила рат Енглеској (1793). Неколико година касније, када су почели мировни преговори, написао је четири Писма о миру краљеубица (1796), не пристајући на крај рата који није испунио циљ - отклањање опасности од ширења револуције, њене „наоружане доктрине” и система „непријатељског према свим другим владама” (Burke, 2010, p. 48).

Берковој критици Француске револуције не може се оспорити далековидост. Први је уочио стремљење ове револуције ка терору и предвидео: 1) да ће револуционарна власт употребљавати радикално насиље да би се одржала, 2) да ће оснивање преког револуционарног суда довести до гушења свих слобода, 3) да ће револуционарна власт огрезнути у корупцији, што се догодило у време Директоријума, 
4) да ће Париз у политичком смислу однети превагу над провинцијама и 5) да ће револуција завршити под чизмом једног генерала кога ће војска подржати због његових личних особина и способности, што се догодило 1799. године, када је Бонапарта (Napoleon Bonaparte, 1769-1821) извршио државни удар (Berk, 2001, str. 58, 64, 160, 174, 182-183). Он је предосетио и трансформацију рата (Burke, 2010, p. 48). Берк, међутим, није предвидео далекосежне последице војне реформе на саму војну организацију. Неискуство у војним пословима сигурно није био разлог томе, јер је он једно време био главни благајник војске у виговској влади лорда Рокингама (Charles WatsonWentworth, Marquess of Rockingham, 1730-1782), па је сагледао устројство војске и стекао увид у начин обављања неких војних послова.

Разлог није ни незаинтересованост за војна питања. Да Берку војне теме нису биле стране показује и један виговски поднесак краљу, написан за време побуне колонија у Америци у Берковој редакцији, у коме се описује опасност коју за енглеско друштво може да представља јачање сопствене копнене војске. Касније, проучавајући владавину револуционара у Француској и тражећи у њиховим поступцима „тајну њихове политике”, Берк као једно од средства помоћу којих вође револуције намеравају да одрже националну кохезију означава националну војску (Berk, 2001, str. 58). И своје најзначајније дело Размииљаға о франиуској револуцији (1 у 790) овај британски филозоф почео је и завршио помињући управо војску: прво не желећи да честита Французима на освојеној слободи док време не покаже да ли је она усклађена, између осталог, и с дисциплином и покорношћу војске (Berk, 2001, str. 6), а на крају разматрајући војну реформу спроведену у Француској и предвиђајући личну власт војног диктатора (Berk, 2001, str. 175-189).

Могло би се рећи да је Берк био веома заинтересован за војна питања јер је управо на тим питањима доказивао неодрживост, узалудност и лошу концепцију политике револуционара и саме револуције, користећи истовремено друштвену реалност Француске у доба револуције (каквом је он опажа) да би показао њен негативан утицај на војску, која ће управо због тога доћи главе и револуцији и њеним посленицима.

Берк је добро знао да „није лако добро уредити војску - ништа не тражи толико пажње" и вероватно је ликовао док је исписивао упозорење својим противницима револуционарима да су покушавајући да примене начела револуције у таквој организацији као што је војска „ухватили вука за уши” (Berk, 2001, str. 175). Имајући у виду његову луцидност и далековидост као критичара револуције, истрајност у агитацији за рат против Француске и његову заинтересованост за војску и војне послове, сматрамо важним да одговоримо на битно, а ипак запостављено питање: У чему се огледа Берков допри- 
нос разумевању војске као друштвене институције? Каква мора да буде друштвена природа војне организације, какви друштвени односи треба у њој да владају и на који начин она треба да буде повезана са другим елементима друштвене структуре? Одговоре на ова питања потражићемо у анализи Беркових агрумената против промена у војној организацији коју су уводили револуционари у Француску његовог доба.

\section{АРГУМЕНТИ ПРОТИВ ИЗБОРА ЗА ОФИЦИРСКЕ ДУЖНОСТИ}

Коментаришући једном приликом побуну робова на Хаитију и крвопролиће које је из тог чина проистекло, Берк је завапио да су та зла настала зато што је субординација уништена (Robin, 2011, p. 13). Ово запажање драгоцено је за разумевање Берковог погледа на војску. Према Берковом мишљењу, две основне карактеристике морају да красе ту моћну и наоружану друштвену институцију. Прва је дисциплина као унутрашњи принцип из ког извире војна ефикасност и коју Берк схвата широко као бит унутрашњих друштвених односа међу припадницима војске различито позиционираних у војној хијерархији. Друга је покорност, схваћена као однос потчињавања војних структура цивилној власти, при чему се то покоравање преноси ланцем командовања до војничких маса (Berk, 2001, str. 6, 175).

Имати избор значи имати алтернативу, други пут и другачију могућност, различиту од оне коју нам у наслеђе остављају претходници. Избор може да отвори врата радикалним променама и револуцији, као што је то у Берково доба био случај у Француској. Може и да доведе до промена у друштвеној хијерархији и да поремети мир једног друштва, нарушавајући његову структуру засновану на разликама. Све је то у супротности са Берковим схватањем друштва као постојаног тела састављеног од непостојаних елемената које повезује тајанствена кохезија (Berk, 2001, str. 27). Друштво може да се мења, али друштвене промене треба да буду ограничене на мењање „болесног дела”, то јест онога што је изазвало нужност промене, и то искључиво на начин који гарантује да се неће распасти друштвена и политичка заједница (Berk, 2001, str. 17).

Покушавајући да дискредитује избор као начело легитимности новог поретка и оспори право народа да бира владара, Берк се позива на тековине Славне револуције, наследни основ краљеве власти, старе законе и државно уређење које је историјски проверено. У његовој ризници старих идеја и начела осећа се дух аристократије, тј. залагање за аристократску власт која ће своју снагу обновити враћањем старих врлина и чија политичка снага извире из врлине, иметка, образовања, наслеђа и традиције, а не из воље народа. Берк пише: „Кажу да двадесет четири милиона мора превладати над двјеста хи- 
љада. То стоји ако је уређење краљевства аритметички проблем" (Berk, 2001, str. 42). Али, будући да је реч о друштвеном и политичком проблему, математичка рачуница, по Берковом мишљењу, ту не важи.

Крунски доказ погубности избора Берк налази у војној организацији. Он оптужује француске револуционаре да су тренутну моћ над војском стекли тиме што су ударили у саму срж војске, одвајајући војнике од официра. Војнику је предочено да има сва права човека и грађанина, што значи да је слободан и да се може покоравати само онима које изабере да га воде. Притом, поред стајаће војске, формирана је и национална гарда, врста грађанске милиције, у којој је заживела пракса да војници бирају своје старешине. То није могло да остане непознато војницима у стајаћој војсци, од којих је сваки сматрао да има иста права као и национални гардисти. Берк је тврдио да је тиме нарушено покоравање; војник бира оног кога би морао да слуша (Berk, 2001, str. 181, 183). Последично, официри или они који претендују на официрске положаје понашаће се као кандидати, удварајући се својим бирачима, врло вероватно на штету професионалне ефикасности, што је опасно и у рату (који ће бити изгубљен) и у миру (уколико се војска осамостали следећи сопствене интересе уместо општедруштвених).

По Берковом мишљењу, у новим ратовима које доноси Француска револуција напуштајући традицију ограниченог европског рата, улога официра и угледање војника на официре имаће све већи значај, јер ће само официри обдарени врлином моћи да спрече нечовечно понашање војника на бојном пољу (Daniel \& Smith, 2015, p. 321; Welsh, 1995, p. 159-160). Зато је неопходно да официри буду људи посебног достојанства које се делом заснива на достојанству државе, а не на страстима војничке масе.

Развијајући ову Беркову мисао, може се рећи да се кидањем традиционалне суштинске потчињености војника официрима губи командни однос као однос функционалне координације условљен потребом за хитно доношење оперативних одлука у условима неизвесне ситуације на бојишту и неопходношћу успостављања друштвене овлашћености командног лица за доношење одлука (Ibrahimpašić, 1980, str. 95).

Беркова је заслуга то што је први указао на спој или, боље речено, однос између официра и војника као на неуралгичну тачку структуре једне војске. Аутори који су пре њега разматрали могућности осамостаљења војске, тзв. преторијански проблем и успостављање војничке демократије, нису разрађивали проблем одвајања и осамостаљивања војника од официра, него су указивали на опасност од могућности да популарни официри искористе своје војнике за задобијање политичких позиција и утицаја (Makijaveli, 2005; Bosije, 
2015; Monteskje, 2004); када су и разматрали недисциплинованост војника, било је то само да би истакли ефикасност дисциплиноване војске (Makijaveli, 2013, str. 54), а не утицај такве распуштености на структуру војске или њене шире друштвене последице. Када је револуција у Француској посејала сумњу да официри из редова племства могу бити пријатељи слободе народа и довела до бунта војничких маса против официра племићког порекла, дошло је до таквог одвајања које је Берков аналитички дух непогрешиво препознао као значајно. На месту споја официрског кора и војничких маса дошло је до пуцања командног ланца и прекида субординације, чија је последица за Француску била извесност ратног пораза. До сличног одвајања дошло је и у Русији пред Октобарску револуцију, захваљујући агитацији бољшевика у војним јединицама. Било је то од кључне важности да би нижи официри и војници послушали Лењинов позив да сами пукови на фронту почну преговоре о примирју, у часу када је Главни штаб царске армије одбио да обустави ратне операције. Револуционарни експерименти са изборима официра и војничким окупљањима ради дискутовања о наређењима напуштени су као штетни и нефункционални, у француском случају под влашћу Директоријума и још израженије у време Наполеонове владавине, а у совјетском одмах по претварању Црвене армије из народне у стајаћу војску, што је процес који је Троцки спроводио и пре 8. конгреса 1919. године (Vjatr, 1987, str. 172).

Мада је демократија од Берковог времена до данас неупитно напредовала, војне старешине се ни у најразвијенијим демократијама не бирају, него их поставља и овлашћује одговарајући државни орган, а војска се убраја у професионалне државне органе који своје функције врше на основу специфичних знања, не на основу резултата слободних и демократских избора. Такви државни органи могу и треба да поседују одређени степен аутономије, али пошто „своју функцију врше без верификације на изборима, неопходно је да буду потчињени представницима народа" (Старчевић, 2011, стр. 243).

Однос између официра и војника остао је и данас важан фактор кохезивности војних јединица. Постојање друштвене дистанце, што је последица изражене војне стратификације, утиче како на морал војника тако и на правилно командовање и управљање људским ресурсима, што су показала истраживања америчких социолога после Другог светског рата (Rose, 1946, p. 361-364).

\section{АРГУМЕНТИ ПРОТИВ СЛАБОГ ВРХОВНОГ КОМАНДАНТА}

Чињеница да су многе јединице француске војске избегавале да се уклопе у уставни поредак те државе, одбијале послушност краљу, изражавале непокорност скупштини и законима, прогониле и за- 
робљавале сопствене официре, пљачкале властите благајне и остављале наредбе без извршења - ужасавала је Берка, који је још у младости записао да је овај свет „непријатељ свега што је добро” (Burke, 1830, p. 93). Једна од претпоставки које чине полазиште Берковог погледа на друштво јесте да је човек као друштвено биће самим рођењем ,преузео низ обавеза које настају из особина друштва у коме је рођен - из хијерархијских односа у њему" (Mićunović, 1997, str. 131). Ова хијерархија најизраженија је у војсци, јер се у њој која је „модел ауторитарне организације” (С̆upić, 2001, str. 31) јавља у огољеном облику. Војна хијерархија се, међутим, не завршава у себи самој, него излази из војне сфере у ширу, политичку сферу. Тако се на челу војске у крајњој линији не налази генерал, него државник или политичко тело. Тај политички орган, био он инокосни или колективни, јесте за војску врховни командни ауторитет. Да би одговорио овој улози, потребно је да тај орган задовољи неколико претпоставки: да има одговарајуће надлежности, компетенције и моћ, што му омогућава да у очима војника заиста буде ауторитет.

Убеђен да се облици власти не могу мењати без далекосежних последица и да друштво и држава не могу почивати само на осећању тренутне користи грађана, без општих вредности и начела који ће их повезати (Berk, 2001, str. 72), Берк је критиковао револуционаре због тога што су краљу одузели многа овлашћења у командовању војском, између осталих да унапређује, награђује и кажњава војнике и војне старешине. Он тврди да је лоше решење то што се краљу оставља у надлежност да одлучује о рату и титуларно командује војском, без стварних полуга да ту војску контролише:

„Не може краљ бити смењен напола. Ако он није све у команди војске, није ништа. Каква је то власт номинално на челу војске, према којој та војска не осјећа захвалност, ни страх? Таква једна нула није погодна за управљање једном ствари која је од свих најосјетљивија, за врховну команду над наоружаним људима" (Berk, 2001, str. 182).

Из такве слабости краља као врховног команданта рађа се, према Берку, дух побуне у војсци и њено друштвено осамостаљивање, јер војска неће бити покорна човеку који је краљ само по титули и који нема моћи да спречи мешање политичких странака у оно што због своје друштвене улоге мора да буде у служби општег, а не парцијалног интереса. Уједно, Берк је потцртао значај оне особине војске коју социолози војске називају њеном монистичношћу (Ibrahimpašić, 1980, str. 92), тврдећи да компликовани односи између краља, скупштине, стајаће војске и националне гарде творе чудовиште (Berk, 2001, str. 188).

Уочавајући да у Француској власт лежи у скупштини, Берк разматра и могућност да војска буде потчињена скупштини. Он се по- 
зива на историјско искуство и тврди да су до времена Француске револуције били познати само случајеви неизвесне и несигурне потчињености војске сенату или другом органу народне власти, а да ће та неизвесност у Француској бити увећана утолико што скупштина има кратак мандат од две године. Француска скупштина показала je, по његовом мишљењу, неспособност да се избори са сломом дисциплине у војсци, јер када је војска погазила заклетве и одбила да поштује краљеве указе, скупштина је уместо оштрих мера (казни, истрага, суђења, расформирања појединих јединица) наложила нове заклетве и усвојила нове указе без увођења икаквих нових механизама који би гарантовали њихово поштовање (Berk, 2001, str. 178).

Када је реч о унапрећивању официра, ово до тада краљево овлашћење присвојила је скупштина. Берк то разуме као знак официру да откаже послушност према свима осим према оној странци која ће му донети унапређење. Он предвиђа да ће такав систем унапређивања довести до поделе у официрском кору на странке и да ће то хаотично стање трајати све док се у војсци не појави популарни генерал коме ће се војска потчинити (Berk, 2001, str. 182).

Берк је непогрешиво уочио значај врховног командног ауторитета за потчињеност војне власти цивилној. Критикујући стање у Француској, он јесте потенцирао краљево право командовања над војском не обазирући се на могућност да је краљ тај који ће злоупотребити војску, али када се бавио истим проблемом у својој отаџбини, доследно је заговарао принципе који би онемогућили такву злоупотребу (Јовановић, 1990, стр. 177). По његовом мишљењу, за одржавање поретка од кључне је важности да се војска, упркос својим предностима у организацији и наоружаности, покорава цивилној моћи. Схватајући да војни позив није „политички стерилан”, он решење за потчињеност наоружаних ненаоружанима види у њиховом специфичном међусобном повезивању, с једне стране, и оданости поретку, с друге стране. Тако је Берк антиципирао основне обрисе Фајнерове (Samuel E. Finer, 1915-1993) теорије о цивилно-војним односима, мада је, за разлику од Фајнера, више волео феудалну и витешку оданост војника краљу (Berk, 2001, str. 72). Анализирајући предности војне организације над цивилнима, Фајнер упозорава да није чудо то што се војска буни против цивилних господара, него што их икада слуша (Finer, 2002, p. 6). Он професионализам војних лица види као потенцијални проблем, а не као део добро постављене цивилне контроле војске. Официри занети професионализмом могу да схвате себе као најкомпетентније да дефинишу и остваре државне интересе. Друштво за њих може да постане само резервоар различитих ресурса помоћу којих се остварују њихови планови (Finer, 2002, p. 25-27). Зато је једно решење, по Фрајнеровом мишљењу, да војска усвоји принцип супрематије цивилне моћи (Finer, 2002, p. 28), на шта је Берк већ упозоравао крајем 18. века. 
У војскама савремених демократски уређених држава питање компетентности врховног командног ауторитета, који је најчешће цивил без посебног војног образовања, решено је тако што му се на располагање ставља војни орган састављен од најискуснијих војних старешина. Његов ауторитет и његова моћ, осим што се наслањају на традицију и политичку културу, имају изворе у надлежностима прописанима највишим правним документима, међу којима су и пријем у службу, постављење и унапређење официра или макар носиоца највиших војних чинова. Из наведеног следи да је Беркова критика упућена француским револуционарима у вези са смањивањем краљевих надлежности у вези са војним пословима задржала своју свежину, док је његов захтев да се војсци усади покорност према цивилној моћи поставио теоријски фундамент за једну од најбољих савремених теорија цивилно-војних односа.

\section{АРГУМЕНТИ ПРОТИВ ДЕЛОВАЬА СТРАНАКА У ВОЈСЦИ И ПОЛИТИЧКОГ ДЕЛОВАЬА ВОЈНИКА}

У потчињености војске скупштини Берк је видео двоструку опасност. Једна проистиче из позиције официра који да би напредовали у каријери морају да постану исувише блиски политичкој опцији која би њихово напредовање подржала у представничком дому, а друга се огледа у опасности да локалне политичке вође, уз благослов или прећутну подршку својих централа и скупштинских посланика, преузму команду над војним јединицама у својим општинама. Прва води у некомпетенцију, друга може довести и до грађанског рата.

Берк је, дакле, уочио опасност од политизације официрског кора и његове странчарске фрагментације. Док је у идеалном случају покоравање неспорној краљевској власти војску чинила релативно отпорном на политички уплив некакве странке или клуба, сада се јавља нови политички изазов - подложност војске утицају политичких странака. Инсистирајући на значају компетентности официра и њиховој потчињености држави, а не странци, Берк је утро пут за развој мисли о цивилно-војним односима ка Хантингтоновој тези о објективној цивилној контроли војске која се остварује повећањем војног професионализма у што већој мери (Hantington, 2004a, str. $92)^{2}$. Берк је наглашавао и значај оданости војске поретку (који укључује и политичку културу), што је претпоставка њене стварне пот-

\footnotetext{
${ }^{2}$ Чак и Хантингтоново запажање да војске „обично не воле да испробавају оружје на грађанима које имају дужност да бране" (Hantington, 2004b, str. 193) неодољиво подсећа на варирање Берковог става да ће енглеска војска, ако у рату против колонија буде научила да пуца у грађане енглеске крви, то исто учинити и у отаџбини (Јовановић, 1990, стр. 177).
} 
чињености цивилним властима. Слично овоме, Хантингтон објективну цивилну контролу види као процес умањења војне моћи у политичком простору путем мотивисања професионалних припадника војске војничким идеалом лојалности држави. И Хантингтонова је мисао окренута официру. Одговорност према држави, а не политичкој странци, лојалност држави, а не партикуларним интересима, чини официра политички неутралним стручњаком за управљање насиљем, у чијем је систему вредности лојалност високо изнад експертизе, због чега је цивилна демократска контрола војске уопште могуha (Hantington, 2004a, str. 80, 82, 93).

Из извештаја већ поменутог државног секретара министарства рата Берк цитира детаље који говоре у прилог томе да општине преузимају надлежност над трупама, упркос томе што је скупштина право командовања војском оставила краљу. Општинске власти прешле су границу између војних и цивилних власти и себи присвојиле право да ражалују официре, да им суде, наређују и да терају војнике са стражарских места (Berk, 2001, str. 179). Јачајући утицај на војне јединице, локалне политичке вође појачавале су властиту моћ у односу на своје политичке противнике.

Уплитање политичких странака у војску производи и опасну реакцију - уплитање војника у политику. Када пропадне друштвени поредак, а систем вредности и норми се распадне на недовољне и неупотребљиве парчиће, недостатак целине (друштвеног поретка, система вредности) очитује се у свим деловима друштва. Кварење једног дела рефлектује се у другом: иза разарања војне дисциплине назире се разбуктала политичка борба која се више не води по устаљеним правилима нити на правно допуштен начин, а недисциплиноване војне старешине и војници, сврставајући се уз различите политичке актере на основу својих интереса, очекивања и надања, придају овој политичкој борби звук звецкања сабљама - она се радикализује и постаје борба на живот и смрт. „Војна анархија разоткрива цивилну, а цивилна показује војну”, сажима ово узајамно кварење Берк (Berk, 2001, str. 180) схватајући попут неоинституционалиста да свака институција дела у ширем окружењу које на њу утиче. Он у томе види тенденцију јачања плебејског елемента, који се наоружава истом брзином којом се аристократски елемент разоружава. Његова предвиђања војничо-народњачких клубова су суморна и засигурно своје утемељење имају у његовом познавању социјалног миљеа британске најамне војске, посебно њених копнених снага чији су припадници често врбовани међу криминалцима (Parkinson, 2000, p. 20-21).

Повезивање недисциплинованих војника и најекстремнијих грађана (Berk, 2001, str. 180), предвиђа Берк, водиће у даље одвајање војника од њихових официра и увести друштво у стање увек могуће побуне. 
Занимљиво је да се идеја политичког ангажовања обичних војника јављала само у револуцијама (Пуританској, Француској и Октобарској), док се о политичком ангажовању официра дуго водила полемика између оних који су сматрали да „официри неће бити најслабији међу посланицима” (Жомини, 1952, стр. 81) и других који су тврдили да војска у пословима државе учествује само као инструмент и сила, па да се зато „војске и не тиче да ли управни државни органи рђаво врше своју дужност и да ли они уводе народ у неправедна предузећа" (Гаве, 1993, стр. 106). Берк припада другима и тај став је преовлађујући, мада се полемика наставља, с новим аргументима, и односи се на све припаднике војске, без обзира на чин. Главна дилема остаје: Да ли је припадник војске политички неутралан професионалац или грађанин у униформи који има одређена политичка ограничења, али само док је на радном месту? Чињеница је да ни у Немачкој, у чијој је војсци у другој половини 20. века уведен концепт грађана у униформи (који подразумева да војник и старешина имају сва политичка права као и други грађани укључујући и пасивно бирачко право и чланство у политичким партијама, да буду политички информисани, заинтересовани за друштвене и политичке проблеме, да прихватају војне обавезе на основу властитих убеђења и учествују у радним саветима војних јединица), бављење војних лица политиком не пролази без проблема који се огледају у отежаном командовању и запостављању војне ефикасности, с једне стране, па до међусобног повезивања и протежирања у војној служби оних војних лица који припадају истој политичкој странци (Старчевић, 2011). Вишедеценијско функционисање концепта грађанина у униформи, уз извесне недостатке који се колико је то могуће спречавају, наизглед и само донекле оповргава Беркову аргументацију у погледу учешћа припадника војске у политичком животу. Али, ако би се политичке поделе у војсци недвосмислено појавиле и у критичним тренуцима појачале, оне би нужно водиле у неефикасност војске као оружане снаге једне државе, а потенцијално и у опасност од оружане побуне, војног пуча или грађанског рата.

\section{ЗАКЉУЧАК}

Берк је, разматрајући друштвене појаве и политичке процесе, заузимао специфично социолошко гледиште и с тог аспекта је сагледавао и војску, при чему његове анализе и критике имају вредност и за савремену социологију војске.

Када је реч о Берковим аргументима против избора за официрске дужности, у прилог њиховој актуелности говори чињеница да су револуционарни експерименти са изборима официра и војничким окупљањима ради дискутовања о наређењима напуштени као штет- 
ни и нефункционални, а да је однос између официра и војника остао важан фактор кохезивности војних јединица у свим савременим војскама света. Берк је био први велики политички филозоф који је указао на однос између официра и војника као на срж једне војске и средишну тачку њене структуре. Одвајање војника од официра била је једна од последица Француске револуције, која Берку није промакла и он је оштро критиковао тај прекид командног ланца, слабљење војне дисциплине и довођење официра у улогу кандидата на војничким изборима за официрске положаје.

Беркови аргументи против слабог врховног командног ауторитета могли би се сажети два захтева: за супрематијом цивилне моћи над војном и за давањем важних надлежности државном органу који за војску има улогу врховног команданта. Берк је показао да његов ауторитет и његова моћ, мада имају упориште у политичкој култури и традиционалним обрасцима, почивају на надлежностима битним за статус војних лица - што је задржано у савременим војскама.

Берк је уочио опасност од политизације војске, политичких подела у официрском кору, уплитања војника у политику, здруживања недисциплинованих војника и политичких екстремиста, политичких злоупотреба војних јединица и деловања војске као самосталне организације способне да доноси и спроводи своје одлуке. Аргументујући разлоге због којих војска не треба да се уплиће у политику, а политичке странке да имају утицај у војсци, Берк је истицао значај компетентности официра и лојалности официрског кора, чиме је антиципирао основне обрисе Фајнерове и Хантингтонове теорије цивилно-војних односа. Био је уверен да је за државу добро када има поуздану и потчињену војску као свој инструмент, а лоше када војска стекне друштвену самосталност и постане господар у држави коју треба да брани. Брану за ову лошу појаву Берк је видео с једне стране у дисциплини као специфичном унутрашњем друштвеном односу који мора да влада у војсци, а с друге стране у потчињавању војске држави, тачније једном државном органу чијим се законитим одлукама мора повиновати читава војна хијерархија.

Предвидео је да ће револуција, са својим утицајем на војску, завршити у диктатури популарног генерала способног да се наметне војсци као неприкосновени вођа. Ово предвиђање било је резултат критичког посматрања револуције, али и аргумент против револуције као начина остваривања друштвених промена. Диктаторском режиму Берк не признаје легитимност, али га донекле оправдава, под условима да поново успоставља поредак у доба кризе када је на делу слом легитимне власти и да доприноси унапређивању државе. Оно што Берк није успео да уочи у војној реформи спроведеној током Француске револуције јесте чињеница да је та реформа напуштањем феудалне најамничке армије као облика војног организовања и уво- 
ђењем опште војне обавезе довела до стварања новог типа војске и означила почетак развоја официрског професионализма који ће потпуно потиснути аристократски принцип кооптације племића у официрки кор. Он, такође, није имао у виду да постојање изразите друштвене дистанце као последице изражене војне стратификације негативно утиче како на морал војника тако и на правилно командовање и управљање људским ресурсима. Ипак, Берк је без сумње дао значајан допринос проучавању војске као друштвене институције, а његов поглед на структуру војске и цивилно-војне односе и данас одише необичном актуелношћу.

\section{ЛИТЕРАТУРА}

Arendt, H. (1990). On Revolution. London: Penguin Books.

Armitage, D. (2000). Edmund Burke and Reason of State. Journal of the History of Ideas, 61(4), 617-634. doi:10.1353/jhi.2000.0033

Berk, E. (2001). Razmišljanja o francuskoj revoluciji [Reflections on the Revolution in France]. Podgorica: CID.

Bosije, Ž. B. (2015). Rasprava o opštoj istoriji. Beograd: Dereta.

Burke, E. (1767). A Philosophical Enquiry into the Origin of our Ideas of the Sublime and Beautiful. London: J. Dodsley, Pall-mall.

Burke, E. (1975). On Government, Politics and Society. London: Fontana.

Burke, E. (1999). Select Works of Edmund Burke, vol. 1. Indianapolis: Liberty Fund.

Burke, E. (2010). Select Works of Edmund Burke, vol. 3. Indianapolis: Liberty Fund, The Online Library of Liberty.

Burke, E., Dennis, Wm., W. C. (1830). Unpublished Remains of Edmund Burke. The National Magazine, 1 (1): 90-97.

Byrne, W. F. (2006). Burke's Higher Romanticism: Politics and the Sublime, XIX (1 and 2), 14-34.

Callaway, H. G. (2016). Edmund Burke, the Imperatives of Empire and the American Revolution: An Interpretation. Newcastle: Cambridge Scholars Publishing.

Čupić, Č. (2001). Politika i zlo [The Politics and the Evil]. Beograd: Čigoja štampa, Fakultet političkih nauka Univerziteta u Beogradu.

Daniel, J. F. \& Smith, B. A. (2015) Burke and Clausewitz on the limitation of war. Journal of International Political Theory, 11(3), 313-330. doi: $10.1177 / 1755088215569368$

Дјурант, В. (2004). Русо и револуиија [Rousseau and the Revolution]. Београд: Војноиздавачки завод, Народна књига.

Esdaile, C. (2007). Napoleon's Wars. London: Penguin books.

Finer, S. (2002). The Man on Horseback, The Role of the Military in Politics. New Jersey: Transaction Publishers.

Freeman, M. (1980). Edmund Burke and the Critique of Political Radicalism. Chicago: University of Chicago Press.

Гаве, А. (1993). Вештина командоваъа [The Art of Command]. Београд: ВИНЦ.

Hantington, S. (2004a). Vojnik i država, teorija i politika civilno-vojnih odnosa [The Soldier and the State, the Theory and Politics of Civil-Military Relations]. Beograd: Centar za studije Jugoistočne Evrope, Fakultet političkih nauka Univerziteta u Beogradu, Diplomatska akademija MSP Srbije i Crne Gore. 
Hantington, S. (2004b). Treći talas: demokratizacija na kraju dvadesetog veka [The Third Wave, Democratization in the Late Twentieth Century]. Beograd: Stubovi kulture.

Hart, J. (1997). Edmund Burke and the English Revolution. Modern Age, 39 (winter 1997), 11-20.

Hejvud, E. (2004). Politika [Politics]. Beograd: Clio.

Ibrahimpašić, M. (1980). Rat kao oblik društvenog sukoba i armija kao društvena institucija [The War as a Form of the Social Conflict and Military as a Social Institution]. Beograd: Vojna akademija.

Janković, I. (2004). Remek-delo vigovskog korifeja (Edmund Berk, Razmišljanja o revoluciji u Francuskoj) [The Masterpiece of Whig Coryphaei]. Nova srpska politička misao, XI(1-4) Retrieved 12. 10. 2016. from http://starisajt.nspm.rs/ Prikazi/2004_dejanvuk_strana5.htm\#2.

Јовановић, С. (1990). Из историје политичких доктрина [From the History of Political Doctrines]. Београд: БИГЗ.

Кајтез, И. (2012). Мудрост и мач: филозофи о тајнама мира и рата [The Wisdom and the Sword, philosophers on the secrets of peace and war]. Београд: МЦ „Одбрана”.

Кајтез, И. (2009). Револуциионарно насиље [The Revolutionary Violence]. Београд: Факултет безбедности, Службени гласник.

Kajtez, I. (2017). Wisdom and Sword, vol. II. Saarbrücken: LAP Lambert Academic Publishing.

Клаузевиц, К. (1951). O рату [On War]. Београд: Војно дело.

Kreveld, M. (2010). Transformacija rata [The Transformation of War]. Beograd: Fakultet bezbednosti, Službeni glasnik.

Makijaveli, N. (2005). Vladalac [The Prince]. Beograd: Dereta.

Makijaveli, N. (2013). O итес́u ratovanja [On Art of War]. Beograd: Tenduro menadžment.

Mićunović, D. (2010). Istorija društvenih teorija 2 [History of Social Theories]. Beograd: Zavod za udžbenike.

Mićunović, D. (1997). Socijalna filozofija, ogledi [Social philosophy, essay]. Beograd: Filip Višnjić.

Monteskje, Š. (2004). Razmatranja o uzrocima veličine Rimljana i njihove propasti [Considerations on the Causes of Greatness of the Romans and their Decline]. Beograd: Utopija.

Norman, J. (2013). Edmund Burke: The First Conservative. New York: Basic Books.

Павловић, Т. (1909). Друштвени развитак и војска [The Social Evolution and the Military]. Београд: Нова штампарија „Давидовић”.

Parkinson, R. (2000). The Peninsular War. Ware, Hertfordshire: Wordsworth Editions.

Robin, C. (2011). The Reactionary Mind: Conservatism from Edmund Burke to Sarah Palin. New York: Oxford University Press.

Rose, A. (1946). The Social Structure of the Army. The American Journal of Sociology, 51 (5), 361-364. doi: 10.1086/219843

Sen-Žist, L. A. (1987). Republikanske ustanove [The Republican Institutions]. Beograd: Filip Višnjić.

Stanovčić, V. (2001). Edmund Berk i ideologija konzervativizma [Edmund Burke and the Ideology of Conservativism]. U: Berk E., Razmišljanja o revoluciji u Francuskoj [Reflections on the Revolution in France]. Beograd: Filip Višnjić, str. 314-393.

Stanovčić, V. (2008). Politička teorija, tom 1 [Political Theory, vol. 1]. Beograd: Službeni glasnik. 
Старчевић, С. (2010). Преторијански проблем у савременој политикологији [Praetorian Problem in Modern Politicology]. Војно дело, LXII (зима 2010), 193-209.

Старчевић, С. (2011). Самоконтрола као вид демократске цивилне контроле војске [Self-control as a Form of Democratic Civilian Control of the Military]. Војно дело, LXIII (пролеће 2011), 242-255.

Жомини, А. (1952). Преглед ратне вештине [The Art of War]. Београд: Војно дело.

Welsh, J. (1995). Edmund Burke and International Relations: The Commonwealth of Europe and the Crusade against the French Revolution. New York: Macmillan/St. Martin's Press.

Wood, E. M. (2000). Democracy against Capitalism. Cambridge: Cambridge University Press.

\title{
BURKE'S CONTRIBUTION TO THE STUDY OF THE MILITARY AS THE SOCIAL INSTITUTION
}

\author{
Srdjan Starčević ${ }^{1}$, Ilija Kajtez ${ }^{2}$ \\ ${ }^{1}$ University of Defense, Military Academy, Belgrade, Serbia \\ ${ }^{2}$ University "Union-Nikola Tesla", Faculty of International Politics and Security, \\ Belgrade, Serbia
}

\section{Summary}

Criticizing the social events in France during the French Revolution, Edmund Burke also dealt with military issues. He criticized the changes that the Revolution brought in the military organization in order to point up the futility and harmfulness of the revolution. In this paper we have analyzed three types of his arguments against the reform of the army in France in order to check if those aspects of Burke's views on military are still valid. These are the arguments against electing military officers for the officers' duties, the arguments against a weak supreme commander and the arguments against the interfering of political parties in the military and against political engagement of the soldiers.

Burke was fully convinced that it was good for the government and the state if there was a reliable and subordinate military force as their instrument, but it was bad if the military force gained social independence and became the master of the state. Burke saw the guarantee that the military would remain an instrument of the politics in discipline as a specific internal social relationship that must prevail in the military, and in the subordination of the military to a single national authority, the supreme command authority, whose legitimate decisions must comply with the entire military hierarchy. Stressing the need for the army to adopt the principle of the supremacy of civilian authority over the military, Burke was one of the forerunners of the modern theories of civil-military relations, those of Huntington and Finer.

Burke was the first who highlighted the connection between officers and soldiers as the central point of the structure of a military. The separation of soldiers from the officers was one of the consequences of the French Revolution, and Burke interpreted it as the interruption of the chain of command, the weakening of military discipline, giving the officers the role of candidates to be elected for their positions. The fact that the revolutionary experiments with elections of officers and military gatherings to discuss the orders were soon abandoned as harmful and dysfunctional is a clear argument that Burke was right. 
Burke noted the danger of politicization of the military, political divisions in the officer corps, soldiers interfering in politics, assemblies of undisciplined soldiers and political extremists, political abuse of military units, and the ability of the military to make and implement its own political decisions.

What Burke failed to observe is the fact that military reforms conducted during the French Revolution meant the abandonment of feudal mercenary military as a form of organization, as well as creating conditions for the introduction of a mass military based on general conscription. This led to the creation of a new type of army and the beginning of the development of officers' professionalism that would fully abolish aristocratic principle of co-opting royalty into the officers' corps. He also did not have in mind that the existence of distinct social distance, as a consequence of military stratification, negatively affects the morale of soldiers and the management of human resources. 